\title{
Feldebrő-Bakoldal 1. számú lelőhely kutatásának előzetes eredményei
}

\author{
Gutay Mónika, Bálint Csaba, Péntek Attila, Szegedi Kristóf István, Tóth Zoltán Henrik
}

Kivonat

Feldebrő-Bakoldal 1. számú lelőhelyen 2011-ben Gasparik Mihály paleontológus gyapjas mamut és egy pleisztocén korú róka maradványait tárta fel, ásatása során több limnoszilicit szilánk is előkerült. Az ígéretes eredmények és a későbbi terepbejárások tapasztalatai miatt 2016 június és szeptember hónapok során tervásatást végeztünk a lelőhelyen. Az eddigi feldolgozás alapján a pattintott kőanyag a felső paleolitikum késői szakaszára tehető, a Gravettien entitás Epigravettien fílumához kapcsolható. A kőnyersanyagok regionális és távolsági szinten is változatosak. Az ásatások során beásási nyomok nélkül a pleisztocén üledékrétegekből kerültek elő paleolitikus leletek mellett kerámia töredékek, ez a jelenség további értelmezést igényel.

Abstract

Kulcsszavak

Keywords

Szerző • Author

Hivatkozás • Cite as

Kézirat történet •

Article history

Jogok • Copyright

(ㄷ)(1) $\$$

\section{Preliminary report of an Upper Palaeolithic site Feldebrö-Bakoldal 1}

At the site Feldebrő-Bakoldal 1, Mihály Gasparik paleontologist uncovered remains of a wooly mammoth and a Pleistocene-age fox together with several limnic silicite flakes in 2011. After successful field walkings we conducted an archaeological excavation at the site between June-September 2016. Preliminary results suggests that the excavated lithic material belongs to the Epigravettian phylum of the Gravettian entity. The lithic raw materials are heterogenous in both the regional and extraregional subsample. We recovered ceramic lumps/ sherds in association with the Palaeolithic artifacts, from Pleistocene layers that were devoid of later disturbation. This phenomenon requires further investigations.

Epigravettien fílum, felső paleolitikum, gyapjas mamut, kerámia, terepmunka, tervásatás

Epigravettian, Upper Palaeolithic, wooly mammoth, ceramic material, fieldwork, excavation

Gutay Mónika, Bálint Csaba, Szegedi Kristóf István, Tóth Zoltán Henrik - Dobó István Vármúzeum, 3300 Eger, Vár 1. Péntek Attila: attila.pentek@yahoo.com

Gutay, M., Bálint, Cs., Péntek, A., Szegedi, K. I., Tóth, Z. H. (2016) Feldebrő-Bakoldal 1. számú lelőhely kutatásának előzetes eredményei (Preliminary report of an Upper Palaeolithic site Feldebrő-Bakoldal 1). Litikum 4: 45-52. https://doi.org/10.23898/litikuma0018

Érkezés | Received: 2016. 07. 29. Elfogadás | Accepted: 2016. 09. 02. Közzététel | Published: 2017. 02. 15.

(C) 2016 Gutay et al. Ez egy nyílt hozzáférésű publikáció, amit a Creative Commons 4.0 licensze véd. A termék szabadon használható, terjeszthető és sokszorosítható az eredeti szerző és forrás megjelölése mellett. | This is an open-access article distributed under the terms of the Creative Commons Attribution License, which permits unrestricted use, distribution, and reproduction in any medium, provided the original author and source are credited.

\section{Bevezetés}

Feldebrő-Bakoldal 1. számú lelőhely Heves megyében, a Mátra DK-i részén, Feldebrő község K-i határában, a Tarna-folyó középmagas pleisztocén teraszán, 155-160 m tszf-i magasságban található (1. ábra). A lelőhelyen tervásatást végeztünk 2016.06.18-26. valamint 2016.09.07-16. között. A területet az első (1763-1787), a második (1806-1869) és a harmadik (1869-1887) katonai felmérések térképei is legelőként ábrázolják. A terület É-i részének elnevezése Bakoldal, a D-i részéé pedig Szőlőfő. Szőlő- vagy egyéb mélymüvelés nem volt a területen. A helyszín Farkas Gábor feldebrői erdőmérnök földterülete, aki a 2000-es évek második felétől megszántotta Bakoldal területét. 2011 tavaszán és őszén mamutcsont töredékek és limnoszilicit szilánkok kerültek elő a szántott talajból. Gasparik Mihály paleontológus (Magyar Természettudományi Múzeum Őslénytani - és Földtani Tára) és munkatársai 2012 áprilisában Feldebrő-Bakoldal területén két gyapjas mamut (Mammuthus primigenius) maradványait találták meg 40-70 cm közötti mélységben (Gasparik 2012). A mamutcsontoktól néhány méterre ÉNy-i irányban egy róka maradványai kerültek elő. Az előkerülési körülmények figyelembevétele alapján ez pleisztocén korú sarki róka (Alopex lagopus) lehet. A gyapjas mamut és a róka maradványok közvetlen közelében limnoszilicit szilánkok is voltak. Az őslénytani feltárás közelében elsődleges gyártási termékeket: magköveket, nyersanyagtöredékeket és szilánkokat találtak megmunkált kőeszközök nélkül. A gyapjas mamutoktól származó csontok körül 3 db 8-12 cm-es átmérőjü cölöphelyet azonosítottak. A mamutcsontok alatt megégett, szenesedett csontok voltak. A jelenséget egy paleolitikus húsdepóként értelmezték. A mamutcsontok radiokarbon kora 12 300 200 év BP (13 200-11 800 év cal BC) (DeA-1735). Ez a dátum a Kárpát-medencében talált mamut maradványok korához viszonyítva túlságosan fiatal (Kovács 2012: 17, Table 1), illetve a mamutcsont kollagén tartalma alacsony volt.

\section{A lelőhely régészeti kutatása}

Feldebrő-Bakoldalon a tervásatás előtt 2016 tavaszán két alkalommal végeztünk terepbejárásokat, illetve Stickel János geofizikus és munkatársai folytattak geofizikai felméréseket. A felszíni leletek, főként pattintott kövek É-D-i irányban mintegy 520 m, K-Ny-i irányban 230 m hosszúságú területen szóródtak szét. A pattintott kövek között magkövek, 
szilánkok, pengék, pattintékok, töredékek és kőeszközök (föként vésők) voltak(2.ábra). A pattintott kövek mellett fosszilis csontokat és a lelőhely K-i részén egyetlen darab valószínüsíthetően bronzkori kerámiát és minden bizonnyal hozzá kapcsolódó állatcsontokat gyưjtöttünk. A felszíni leletek szórásintenzitása alapján öt leletgazdag terület különíthető el (3. ábra). Méretei folytán a lelőhely tulajdonképpen egy lelőhelykomplexum, amelynek esetében tehát minden bizonnyal több felső paleolitikus megtelepüléssel számolhatunk.

A területen talajradarral történő felmérést is végeztünk. A talajradar hat anomáliát mutatott ki, amelyekről a második felmérés során kiderült, hogy egy bizonytalan korú és eredetû́ vonalas létesítményhez tartoznak. Nem tekinthetők régészeti objektumoknak.

A júniusi ásatás során a lelőhely különböző pontjain, a leletek legnagyobb felszíni leletsűrüsödései alapján jelöltünk ki a feltárási szelvényeket. Az É-i részen a 4., az 5., a Ny-i részén a legintenzívebb leletszóródási területen a 3., a 8., a 9., a K-i részén a 6., a D-i részén a 7., a 10., a 11., a 12., a 13. és a 14. sorszámmal ellátott szelvényeket tártuk fel. Az 1. és a 2. sorszámmal kijelölt szelvényeket nem ástuk meg (4. ábra).A 3. szelvényben megfigyelt rétegsorok a következők voltak: 0-30 cm sötétbarna színű humuszosodott talaj, 30-60 cm sárgás színü homokos agyag, alatta 60 cm-től világos sárgásbarna sárga színú homok (5. ábra).

A leletek döntő többsége valamennyi szelvényben 30-45 cm mélységben került elő. A leggazdagabb szelvények leleteinek horizontális szóródása a mélységadatok jelzésével a 6. ábrán, a leggazdagabb, 8. szelvény leleteinek vertikális szóródása a 7. ábrán látható. A 3. szelvényben elég sok volt a faszéndarab, míg a mellette levő 8. szelvényből csak kevés faszén került elő (8. ábra). A 3. szelvénytől Ny-DNy-i irányban egy tüzhely maradványa feltételezhető. A szelvényekből pengék, szilánkok, magkövek, töredékek és típusos pattintott kőeszközök (föként tompított hátú lamellák, vésők) kerültek elő.

A szeptemberi ásatás során a feltárási szelvények kijelölésében a megelőző ásatás eredményeire is támaszkodtunk. A lelőhely É-i területén a leletgazdag 8. szelvény ÉK-i irányú részleges, $2 \times 1$ m-es nagyságú bővítésére került sor (8Y szelvény). A D-i részen pedig a különösen kerámiában gazdag 7 . szelvénykomplexum ÉNy-i irányban történő bővítése történt meg egy $2 \times 1 \mathrm{~m}$-es (17. szelvény) és egy $3 \times 2$ m-es (18. szelvény) nagyságú szelvény által. Az ásatás eredményei közül különös jelentőséggel bírhat a 8Y. szelvény gazdag leletanyaga (9. ábra), valamint a 18. szelvényben feltárt tüzelési nyom és az ismételten előkerült jelentősebb mennyiségú régészeti lelet, köztük kerámia (10-11. ábra). A 17. és a 18. szelvényekben talajmintázás is történt. A geomorfológiai vizsgálatokat Dobos Anna geomorfológus (Eszterházy Károly Egyetem) végezte, ezek alapján a lelőhely a Tarna IIb. pleisztocén teraszán helyezkedik el. A szelvény elkülönített rétegsorai: 0-42 cm között sötét sárgásbarna színû, erősen szerkezetes, gyengén cementált iszapos agyag. 42-65 cm között sötét sárgásbarna színű erősen szerkezetes, gyengén cementált, iszapos, homokos anyag. 65-90 cm között világos sárgásbarna színü, gyengén szerkezetes, közepesen cementált, közép és finom szemcsés homok, kevés lösszel. 90-110 cm között sárgásbarna színű, gyengén szerkezetes, gyengén cementált, közép és finom szemcsés homok.

\section{Előzetes eredmények}

A felszíni gyưjtésből származó leletek mellett eddig csupán a júniusi ásatás leleteinek történt meg a feldolgozása és az alapvető statisztikai kiértékelések elkészítése. Az eddig megvizsgált pattintott kőanyag viszonylag kicsiny, 37 darabos eszközkészletének tipológiai képét a vésők, a retusált pengék és lamellák valamint a tompított hátú darabok magasabb aránya jellemzi (12. ábra). A leletegyüttes a késői felső paleolitikumra, a 20-13 000 év BP közé keltezhető, valószínúleg a Gravettien entitás Epigravettien fílumába tartozik (Lengyel 2008; T. Dobosi 2009: 15). Relatív korhatározásunkat természettudományos vizsgálatokkal szeretnénk igazolni. Mind a felszíni gyưjtésekből, mind az ásatási szelvényekből nagyszámú penge, pengetöredék, lamella és lamellatöredék került elő (13. ábra). A felszínről gyűjtöttünk két unipoláris pengemagkövet, két unipoláris lamellamagkövet, illetve egy bipoláris pengemagkövet. A pengék és magkövek morfometriai adatait és technológiai elemzését egy későbbi publikációban kívánjuk közzétenni. A leletegyüttes néhány jellegzetes darabja, eszközök, pengék és magkövek, a 14-19. ábrákon látható.

A pattintott kövek többségének a nyersanyagában kétféle, feltehetôleg regionális eredetû́ limnoszilicit mutatható ki, a mátrai és a mátraderecskei limnoszilicit (20. ábra). Helyidegen nyersanyag a lelőhely D-i részén felszíni gyüjtésből származó, makroszkóposan beazonosíthatatlan eredetű tűzkő, É-i részén, a felszíni gyűjitésből származó kvarcporfír (metariolit) szilánk, továbbá az 5. szelvényből előkerült csehországi tûzkő (21:1. ábra). A régészeti leletanyagokban nagyon ritka nyersanyagnak számító vörös vagy másképpen mahagóni obszidián (T. Biró et al. 2005) lelet került elő (21:2. ábra) a 2012-es mamutfeltárás helyszínétől Ny-i irányban kb. 10-11 m-re nyitott szelvényben. Lengyel György a Gravettien entitás egy új kronológiai besorolását tárgyaló cikkében az északi eredetű tűzkőnek - mint kronológiai jelzésértékű nyersanyagnak - az előfordulásával kapcsolatos kérdésekkel is foglalkozik (Lengyel 2014). Úgy tűnik, hogy a Gravettien entitásban elsősorban az északi eredetû tűzkövek (kréta korú erratikus balti tűzkő, jura korú Krakkó környéki tűzkő) előfordulása vagy hiánya fontos relatív kronológiai ismérv. A. Verpoorte (2004) nyomán, Lengyel György érvelése alapján az LGM alatt és még azt követően is csak kevés északi tűzkő fordul elő az ismert epipaleolitikus leletanyagainkban. Korábban nem ismert mennyiségben jelennek meg ugyanakkor az intenzív K-i kapcsolatok meglétére utaló pruti, volhíniai tüzkőféleségek (Lengyel 2009: 228; 2014: 342). A lelőhely nyersanyag-felhasználásában az északi tűzkő hiánya esetleg a lelőhely korai epipaleolitikus korára (20-17 000 év BP) is utalhat.

A lelőhely D-i részén az átvágott domboldal metszetfalában több gödörszerü jelenséget figyeltünk meg. Az egyik gödör metszet betöltéséből pattintékok kerültek elő. A gödörszerü jelenségek a katonai gyakorlatok eredményeképpen létrejött képződmények lehetnek. 
A júniusi ásatás folyamán a lelőhely különböző részein megásott szelvényekből 24 darab kerámia/agyagtöredék került elő. Szeptemberben a 17. és 18. szelvényekben összesen 147 db kerámia/agyagtöredék került feltárásra (22. ábra). A nagy mennyiségú kerámia töredék közül bemutatunk néhány darabot (21:3-4. ábra). A felszíni gyưjtések során a lelőhely $\mathrm{K}$-i részén egyetlen feltételezett bronzkori kerámia volt. Valamennyi kerámiatöredék a paleolitikus kőanyag mellett, 29-69 cm közötti mélységből látott napvilágot. Ez a jelenség további régészeti értelmezést kíván. Ennek érdekében természettudományos vizsgálatokat szeretnénk végezni a Miskolci Egyetem Ásvány - és Kőzettani Tanszék munkatársával, Kristály Ferenccel együttmüködésben. A kerámiák/ agyagtöredékek előzetes mikroszkópos vizsgálatára már sor került, amely alapján a kerámiákat $400-500{ }^{\circ} \mathrm{C}$ hőmérséklet érhette, ezért nem éghettek ki megfelelően és a megtartásuk is rossz. Egyes leletek szerkezete réteges volt, többségük homokos szerkezetû, amely homokkal történő soványítás eredménye is lehet. Ezek a jellemzők szándékos megmunkálásra utalhatnak. Heves megyében Erk 1. számú mezolitikus lelőhelyen a felszíni gyújtésből és szondákból is kerültek elő kerámia töredékek. Az 1. szondában 50-74 cm közötti mélységben tüzelési nyomok voltak megfigyelhetők, a tüzhely mellett kerámiatöredékekkel, amelyek szintén további vizsgálatokra szorulnak. A 2. szelvény öntés réti talaj rétegéből, a felszíntől számított 41-43 cm közötti mélységéből egy kutyaféle foga került elő. A lelet radiokarbon kora (DeA7424) $9171 \pm 46$ év BP (8 440-8 300 év cal BC). A kutyaféle a preboreális és a boreális határán, a korai mezolitikum idején élt.

A felső paleolitikumban több lelőhelyről ismert égetett agyagtárgy Eurázsiából. A legkorábbi égetett agyagtöredékek a korai felső paleolitikumból a mai Görögország területéről származnak, ahol tapasztott felületen gabona magvakat sütöttek (Kuczyńska-Zonik 2014: 80). A középső felső paleolitikumban Európában a csehországi Gravettien (Pavlovien) lelőhelyeken koncentrálódik ez a leletcsoport, illetve a kelet-európai síkságon (Kostenkien). Csehországi lelőhelyeken előkerült figurális ábrázolásokat $400-800^{\circ} \mathrm{C}$ hőmérsékleten égették ki. Kostienki és Zarajszk lelőhelyeken a kerámiatöredékeket tûzhely vagy kemence részeiként értelmezték, noha számos kerámia íves volt és edénytöredék is lehet (Kuczyńska-Zonik 2014: 83). A Kostienki lelőhelyek kerámiái 23000 év BC-re datálhatóak (Kuczyńska-Zonik 2014: 84). Ezt az időszakot követően jelenik meg főleg Kelet-Eurázsiában a korai edénymúvesség a vadász-gyüjtögetők körében, jelenlegi tudásunk szerint először Délkelet-Kínában a Xianrendong-barlangban 20-19 000 év cal BP körül (Wu et al. 2012). Észak-Kínában, az Amur-folyó vidékén és Japánban (Jomon-kultúra) és több szibériai lelóhelyen ismertek kerámialeletek a Bølling, Allerød interstadiálisok és Dryas III stadiális idejéból is (Cohen 2014; Gibbs, Jordan 2013).

A Feldebrő-Bakoldal-Szôlőfő lelőhelykomplexum gazdag felszíni és ásatásból származó leletanyaga, a leletanyagban tapasztalt régészetileg jelentős sajátosságok mindenképpen indokolják a terület továbbkutatását. A közelben talált Tófalu-Honvéd-halom paleolitikus lelőhely, Tarnaörs-Fodortanya és Erk 1. mezolitikus lelőhelyek gazdag leletanyagai, továbbá a térségben talált számos szórványlelet pedig a teljes Tarna-völgy térségének továbbkutatását teszik szükségessé.

\section{Köszönetnyilvánítás}

Köszönjük a tervásatásban résztvevő régészek, régész-technikusok és munkatársak önkéntes alapon szerveződött munkáját. Szabadidejüket és a munkaerejüket biztosítva részt vettek a feltárási munkákban, szakmai segítséget és anyagi támogatást nyújtottak a kutatásokban: Árgyelán Alexandra, Béres Sándor, Farkas Gábor, Fülöp Marcell, Gasparik Mihály, Gábriel Sára, Gálfi Zoltán, Gálfi-Martos Gyöngyvér, Habi Péter, Kecskeméti Daniella Zoé, Kerékgyártó Gyula, Kristály Ferenc, Lengyel György, Martos Benedek, Máthé Márk Bence Mester Zsolt, Simoncsics Gábor, Stefán József, Stickel János, Szolyák Péter, Ujj Gabriella, Zandler Krisztián.

\section{Irodalomjegyzék}

Biró, K. T., Markó, A., Kasztovszky, Z. 2005. 'Red' obsidian in the Hungarian Palaeolithic: characterisation studies by PGAA. Praehistoria 6: 109-140.

Cohen, D.J. 2014. The Advent and Spread of Early Pottery in East Asia: New Dates and New Considerations for the World's Earliest Ceramic Vessels. Journal of Austronesian Studies 4 (2): 55-92.

Dobos, A. 2016. Üledék - és talajfelvételezés, geomorfológai megfigyelések kutatási jelentés az Eger Dobó István Vármúzeum Régészeti Osztálya számára. Az ERK-1. 1G-Szonda környezetének természetföldrajzi rekonstrukciója. Kutatási jelentés. Kézirat. Eszterházy Károly Főiskola, Környezettudományi és Tájökológiai Tanszék, Eger.

T. Dobosi, V. 2009. A hazai felső paleolitikum vázlata. Tisicum 19: 19-28.

Gasparik, M. 2012. Traces of mammoth hunters (?) from the vicinity of Feldebrő (North Hungary). In: Cyrek, K., Czyzewski, L. A., Krajcarz, M. T. (eds.), European Middle Paleolithic during MIS8 MIS3. Guidebook \& Book of Abstracts. Nicolaus Copernicus University, Toruo, 88-89.

Gibbs, K., Jordan, P. 2013. Bridging the Boreal Forest. Siberian Archaeology and the Emergence of Pottery among Prehistoric Hunter-Gatherers of Northern Eurasia. Sibirica 12 (1): 1-38. https://doi.org/10.3167/sib.2013.120101

Kovács, J. 2012. Radiocarbon chronology of Late Pleistocene large mammal faunas from the Pannonian basin (Hungary). Bulletin of Geosciences, 87(1), 1. https://doi.org/10.3140/bull.geosci.1282

Lengyel, Gy. 2008. Radiocarbon Dates of the „Gravettian Entity” in Hungary. Praehistoria 9-10: 241-263.

Lengyel, Gy. 2009. A ságvári felső paleolit telep és a kárpát-medencei Gravetti kőnyersanyagai. In: Ilon G. (szerk.): Öskoros Kutatók VI Összejövetelének konferenciakötete. Nyersanyagok és kereskedelem. Kőszeg, 2009. március 19-21. Szombathely, 223-231.

Lengyel, Gy. 2014. Distant connection changes from the Early Gravettian to the Epigravettian in Hungary, In: Otte, M., Le Brun-Ricalens, F. (dir.), Modes de contacts et de déplacements au Paléolithique eurasiatique. E.R.A.U.L. 140, Liège, 331-347.

Kuczyńska-Zonik, A. 2014. Gravettien Ceramic Firing Techniques in Central and Eastern Europe. Analecta Archaeologica Ressoviensia 9: 79-94.

Wu, X., Zhang C., Goldberg, P., Cohen, D., Pan, Y., Arpin, T., BarYosef, O. 2012. Early Pottery at 20, 000 Years Ago in Xianrendong Cave, China. Science 336: 1696-1700. https://doi.org/10.1126/ science. 1218643

Verpoorte, A. 2004. Eastern Central Europe during the Pleniglacial. Antiquity 78:257-266. https://doi.org/10.1017/S0003598X0011292X 

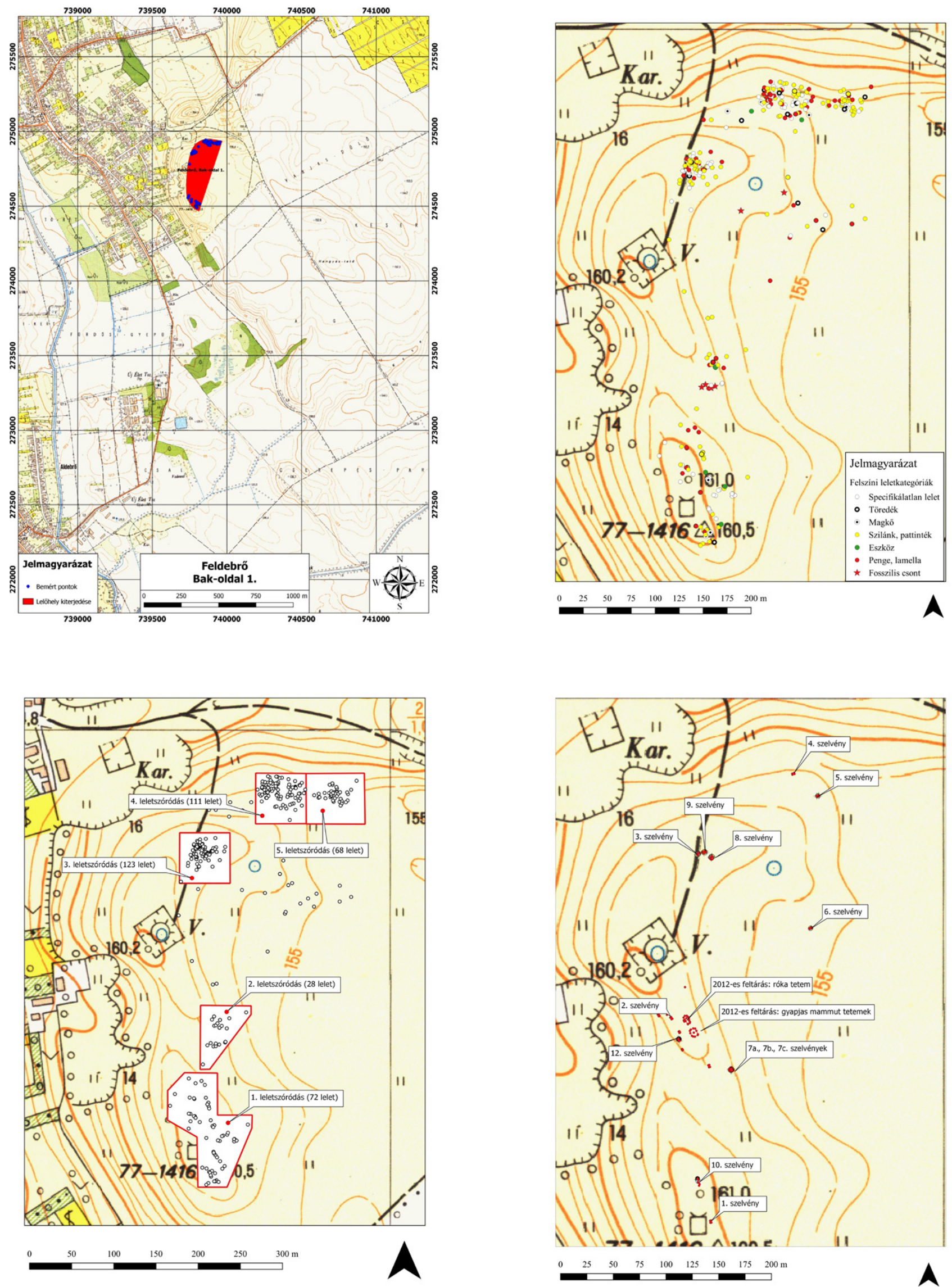

Fentről lefelé, balról jobbra. 1. ábra. Feldebrő-Bakoldal 1. számú lelőhely elhelyezkedése. 2. ábra. Felszíni leletkategóriák. 3. ábra. Felszíni leletek szóródási körzetei. 4. ábra. Feltárási szelvények elhelyezkedései a lelőhelyen. //

Up to down, from left to right. Figure 1. The location of Feldebrő-Bakoldal 1. archaeological site. Figure 2. Categories of surface finds. Figure 3. The areas of intensive surface finds. Figure 4. The location of excavation trenches on the site (June 2016) 

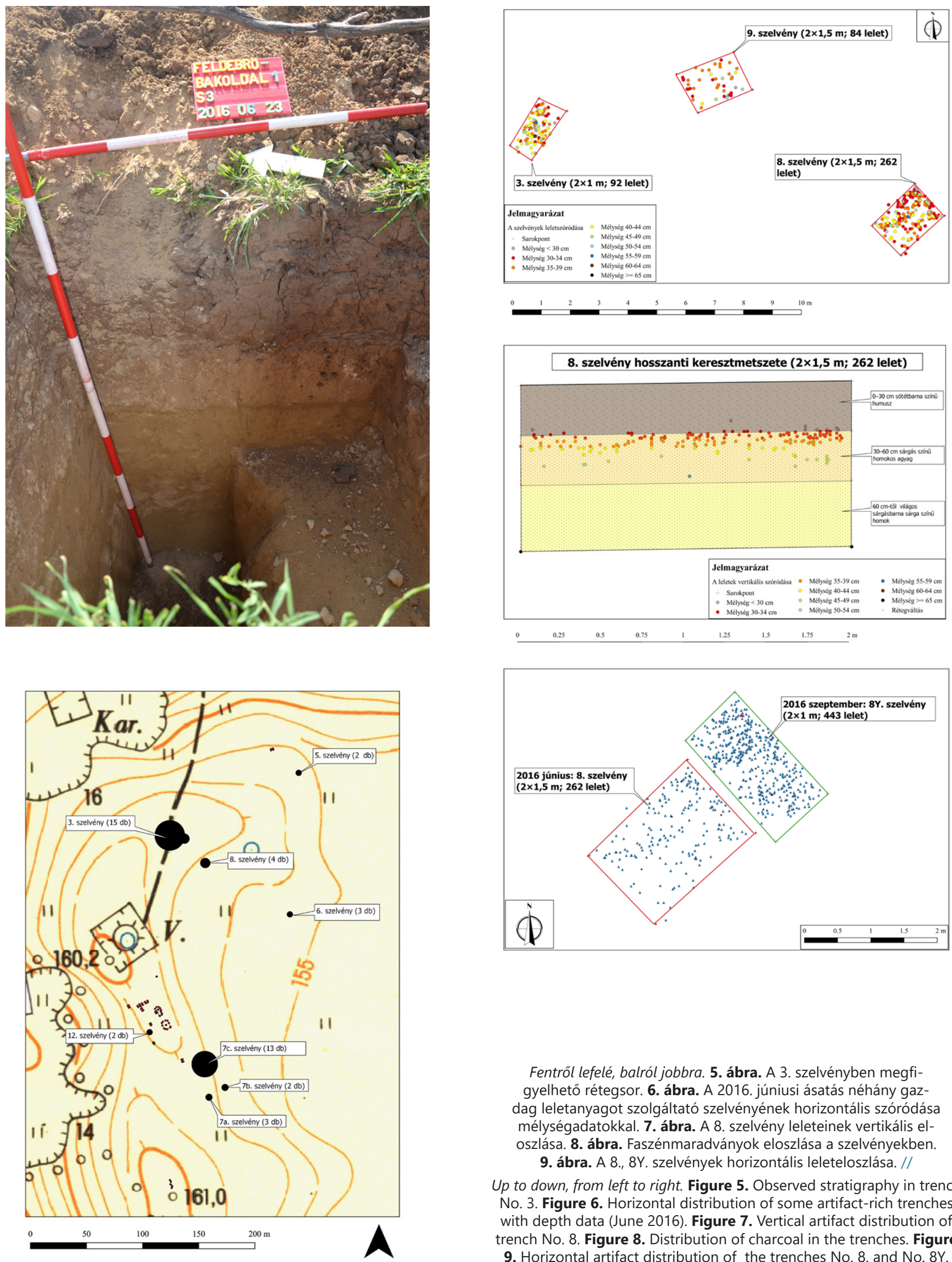

Fentről lefelé, balról jobbra. 5. ábra. A 3. szelvényben megfigyelhető rétegsor. 6. ábra. A 2016. júniusi ásatás néhány gazdag leletanyagot szolgáltató szelvényének horizontális szóródása mélységadatokkal. 7. ábra. A 8. szelvény leleteinek vertikális eloszlása. 8. ábra. Faszénmaradványok eloszlása a szelvényekben.

9. ábra. A 8., 8Y. szelvények horizontális leleteloszlása. //

Up to down, from left to right. Figure 5. Observed stratigraphy in trench No. 3. Figure 6. Horizontal distribution of some artifact-rich trenches with depth data (June 2016). Figure 7. Vertical artifact distribution of trench No. 8. Figure 8. Distribution of charcoal in the trenches. Figure 9. Horizontal artifact distribution of the trenches No. 8. and No. 8Y. 

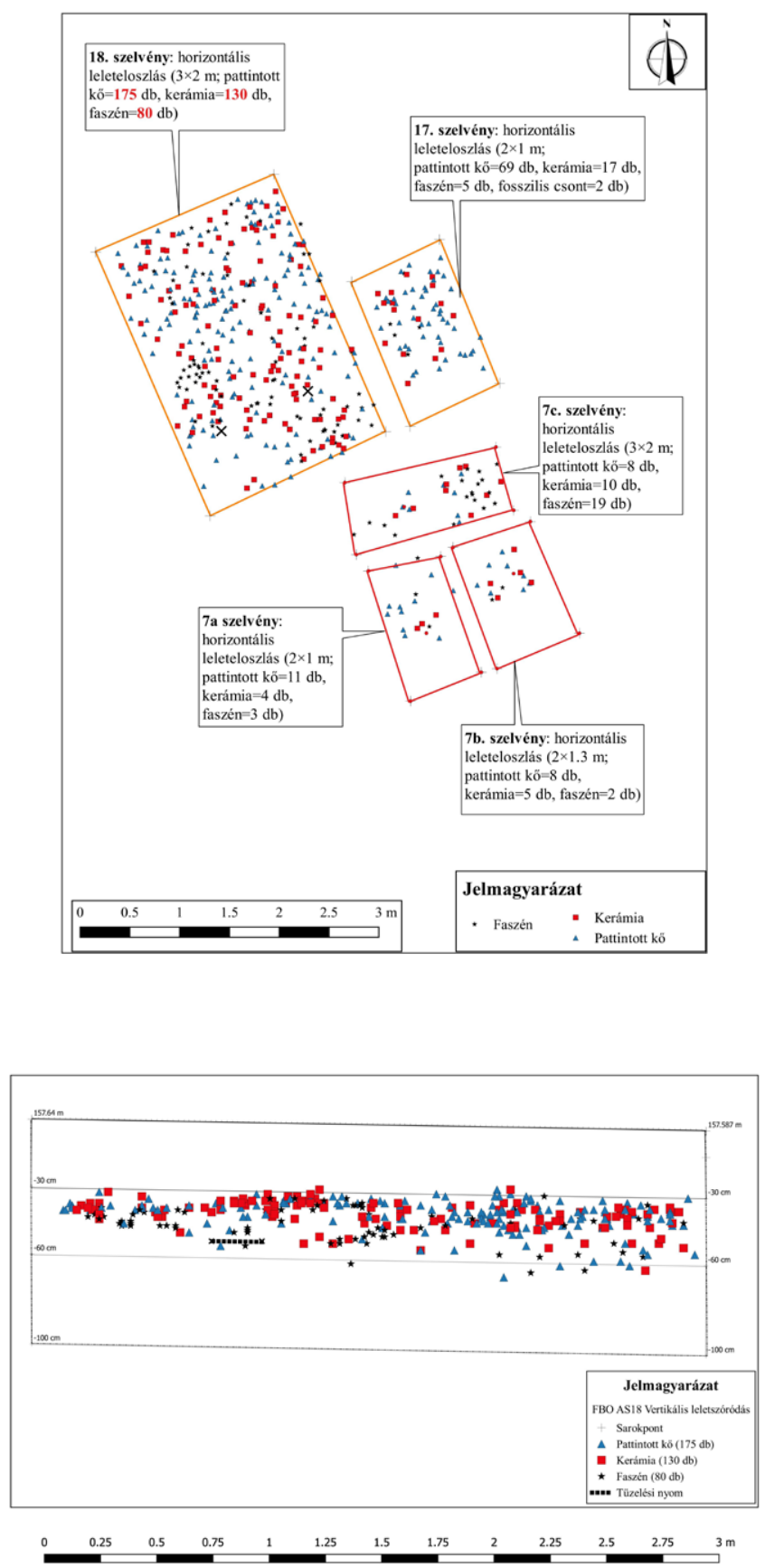

10. ábra (balra fent). A 7a., 7b., 7c., 17., 18. szelvények horizontális leleteloszlása. 11. ábra (balra lent). A 18. szelvény vertikális leleteloszlása három leletkategóriára. 12. ábra (jobbra fent). Az eszköztípusok darabszám szerint megoszlása. 1 = Szilánkvakaró, $2=$ Véső pengén, $3=$ Véső szilánkon, $4=$ Retusált penge, 5= Retusált lamella, $6=$ Retusált szilánk, $7=$ Fogazott szilánk, $8=$ Tompított hátú darab, 9= Egyéb megmunkált darab. //

Figure 10 (above left). Horizontal artifact distribution of the trenches No. 7a., 7b., 7c., 17., 18. Figure 11 (below left). Vertical artifact distribution of trench No. 18. for three artifact categories. Figure 12 (above right). Distribution of the main tool types. 1=End-scraper, $2=$ Burin made on blade, $3=$ Burin made on flake, $4=$ Retouched blade, $5=$ Retouched microblade, $6=$ Retouched flake, $7=$ Denticulate $8=$ Backed piece, $9=$ Other retouched tool.
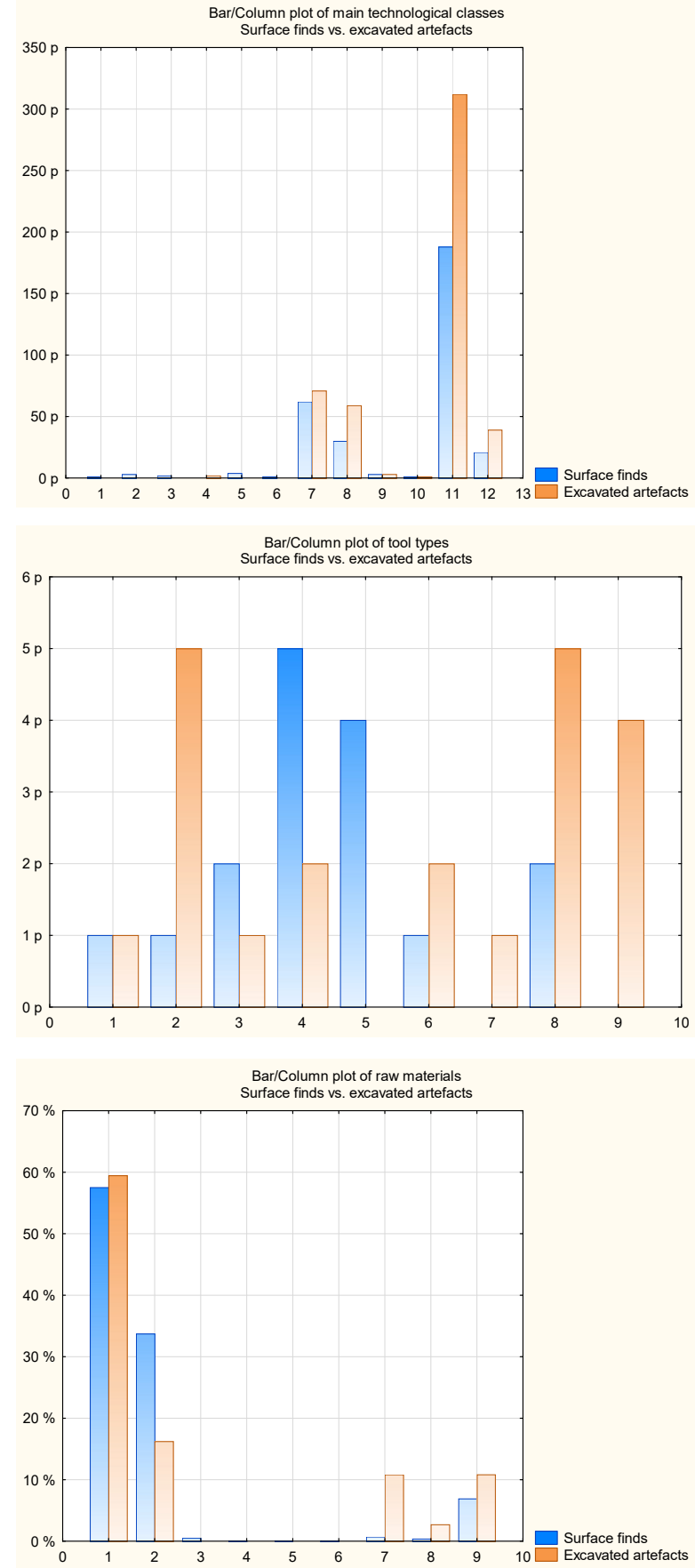

13. ábra (jobbra középen). A fő technológiai csoportok darabszám szerint megoszlása. $1=$ Bipoláris penge magkő, $2=$ Unipoláris penge magkő, 3=Unipoláris lamella magkő, 4=Szilánk magkő, 5= Nem hierarchizált magkő, 6=Magkő kezdemény, 7= Penge, pengetöredék, 8= Lamella lamellatöredék, $9=$ Vésőpattinték, $10=$ Gerinc penge/szilánk, 11=Szilánk, $12=$ Nyersanyaghulladék, törmelék. 20. ábra (jobbra lent). A felszíni és a 2016. júniusi ásatás leleteinek százalékos nyersanyageloszlása. 1=Mátra-Gyöngyös típusú limnoszilicit, 2=Mátraderecske típusú limnoszilicit, 3=Kalcedon, 4=Mészkő, 5=Tufa, 6=Kvarcporfír, 7=Obszidián, 8=Tűzkő, $9=$ Beazonosíthatatlan. //

Figure 13 (middle right). Distribution of the main technological classes. $1=$ Bipolar blade core, $2=$ Unipolar blade core, 3=Unipolar microblade core, 4=Flake core, 5=Non-hierarchized core, $6=$ Pre-core, $7=$ Blade, blade fragments, $8=$ Microblades, microblade fragments, 9=Burin spall, $10=$ Crested blade/flake, $11=$ Flake, $12=$ Waste product. Figure 20 (below right). Raw material distribution of surface finds and those artifacts excavated in June 2016. 1=Mátra-Gyöngyös-type limnic silicite, 2=Mátraderecske-type limnic silicite, 3=Chalcedon, 4=Limestone, 5=Tuff, $6=$ Felsitic porphyry, $7=$ Obsidian, $8=$ Flint, $9=$ Unidentified. 

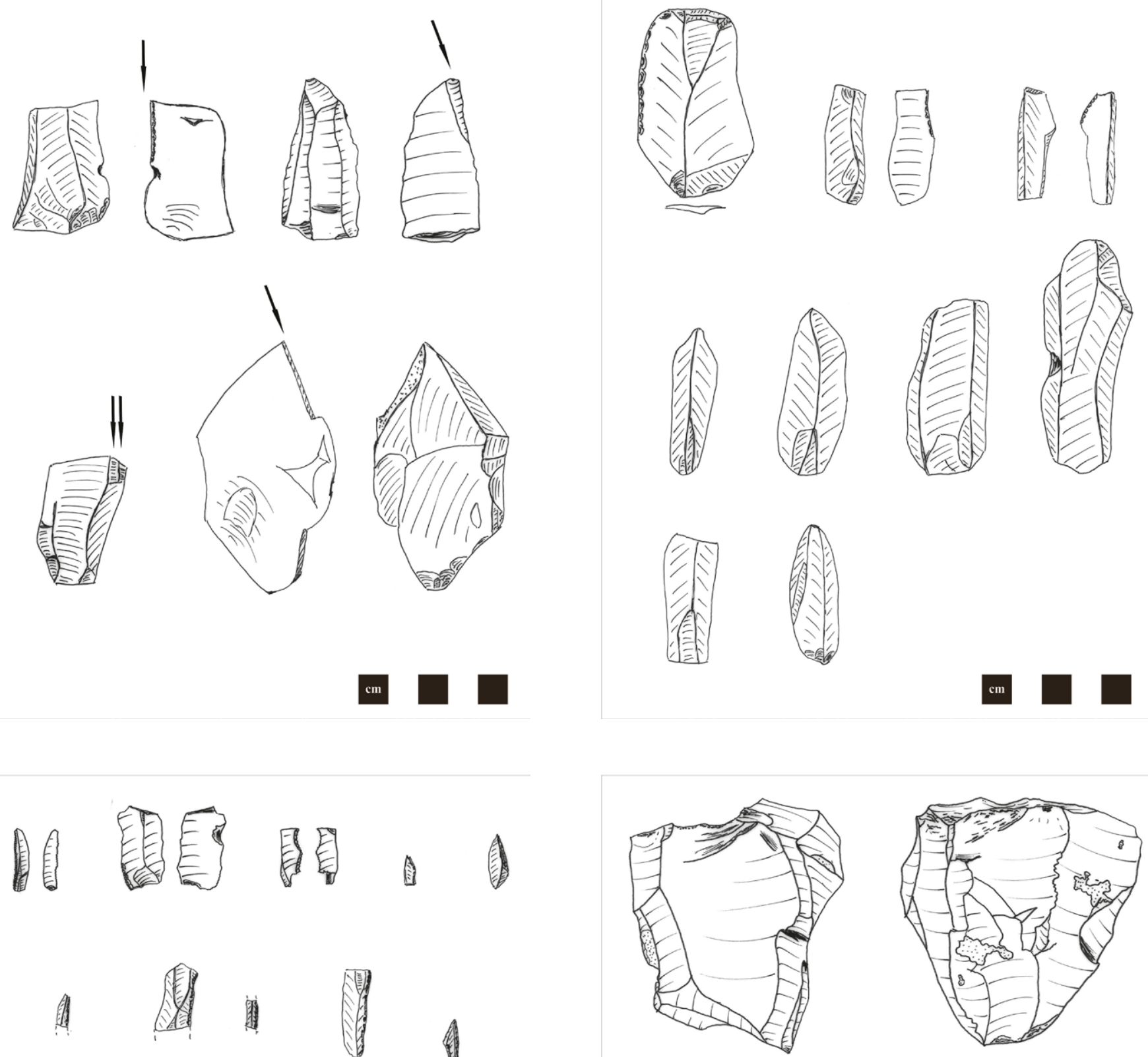

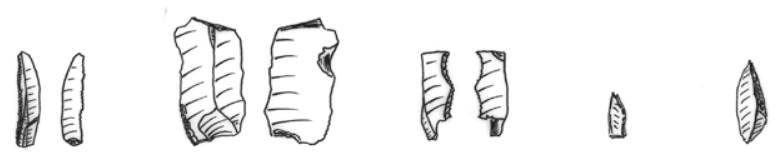

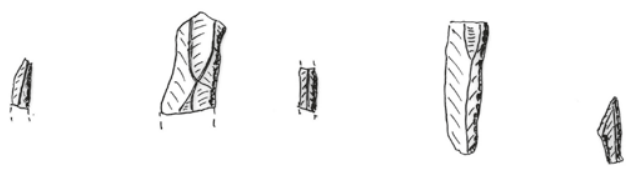
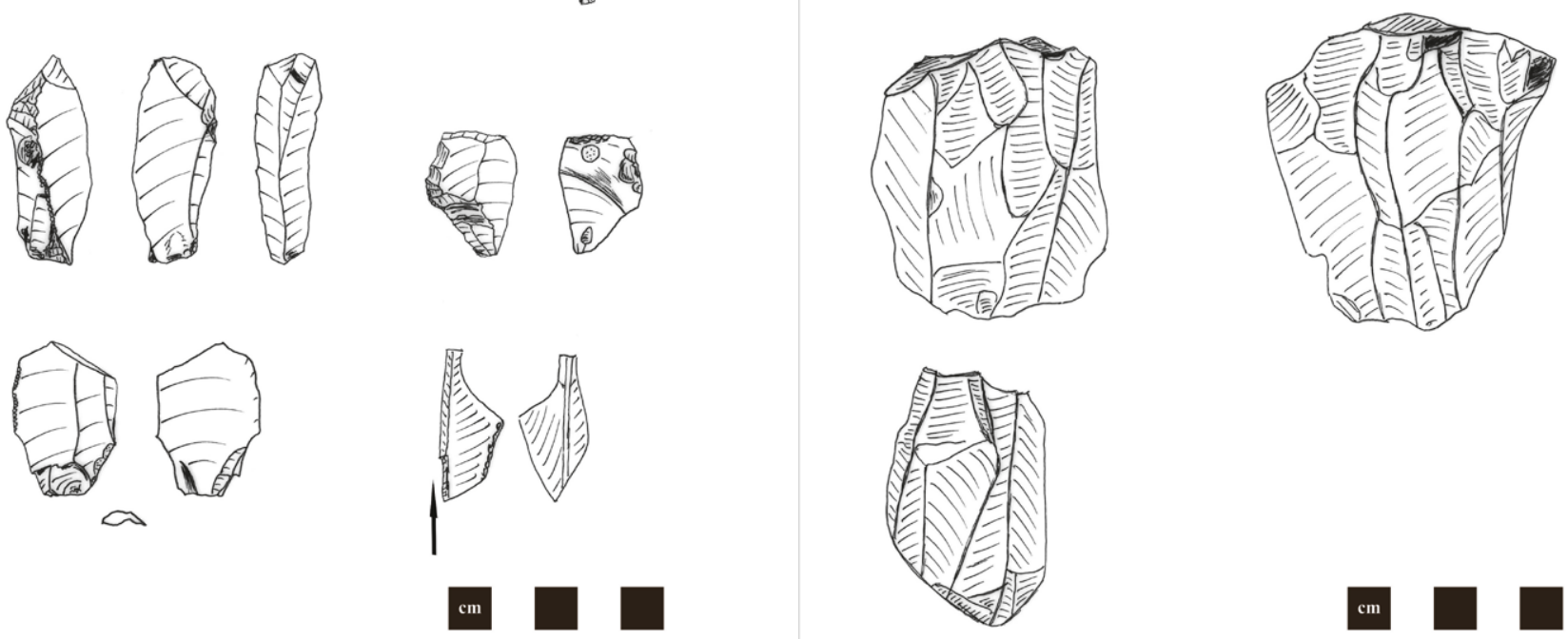



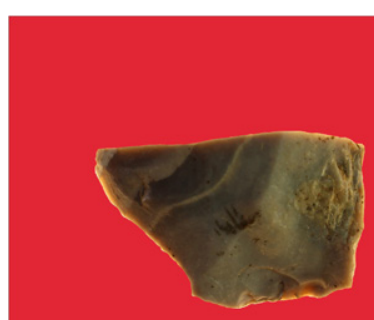

1

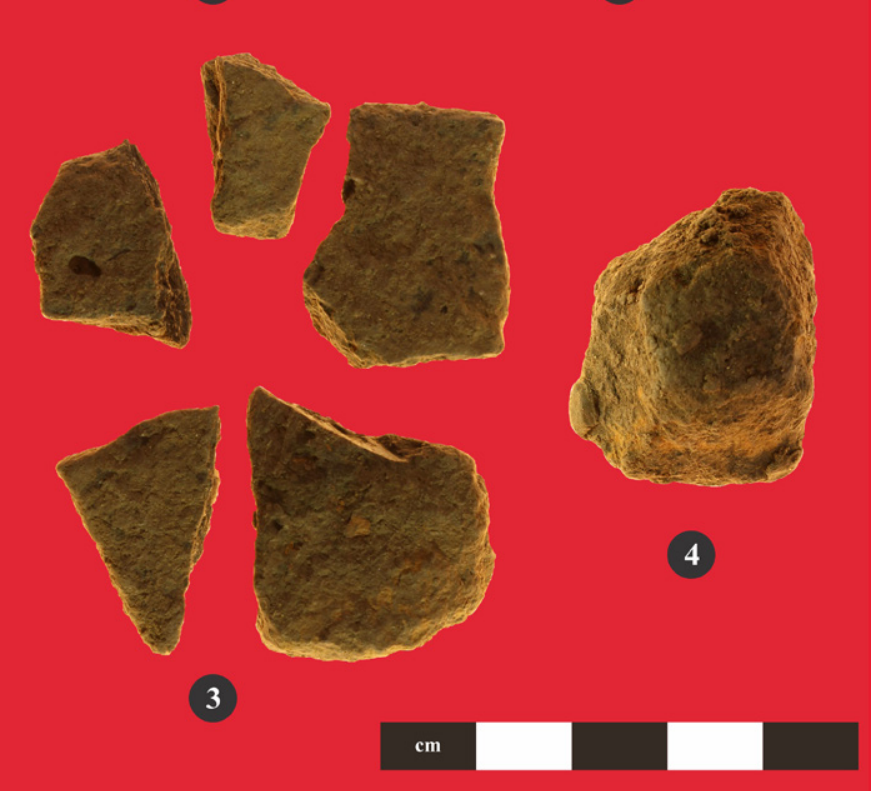

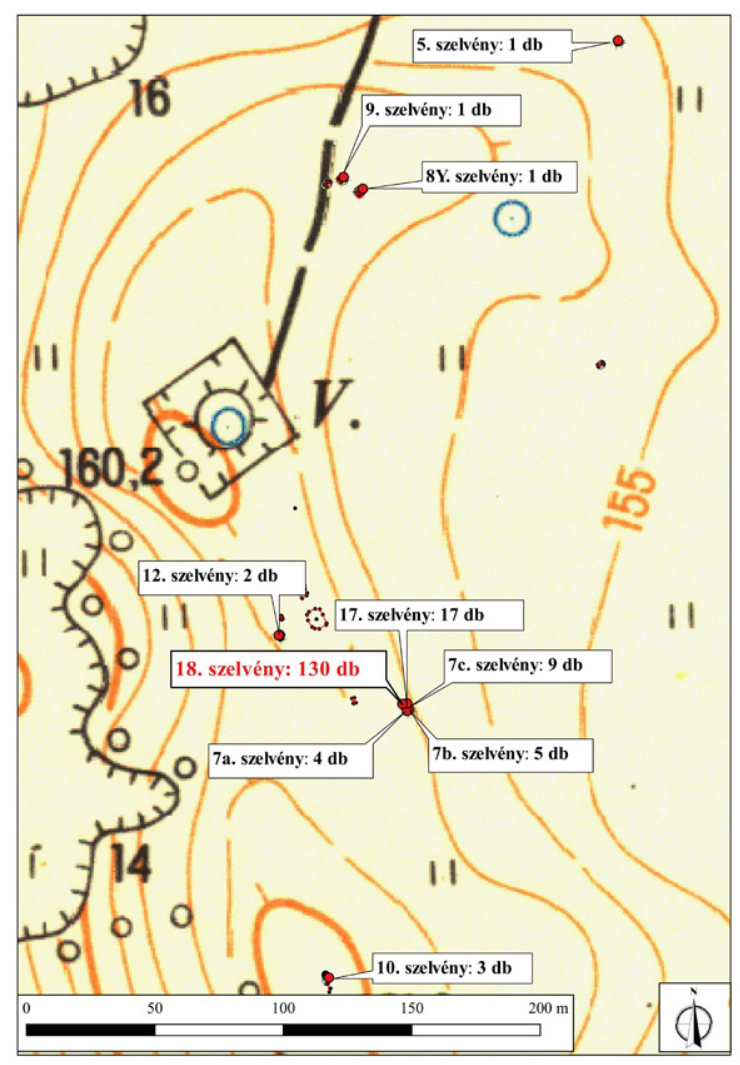

Fentről lefelé, balról jobbra. 18-19. ábra. Válogatott leletek a lelőhely kőanyagából. 21. ábra. Csehországi tűzkő, mahagóni obszidián és kerámia töredékek. 22. ábra. Kerámialeletek elhelyezkedése a szelvényekben. //

Up to down, from left to right. Figure 18-19. Selected artifacts from the site. Figure 21. Moravian flint, mahogany obsidian and ceramic fragments. Figure 22. The distribution of ceramic finds from the trenches. 